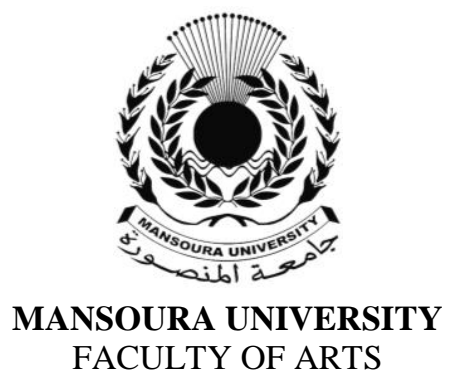

$-$

\title{
Sam Shepard's The God of Hell An Ecocritical Reading of a play Essentially Political
}

BY

Dr. Abdullah Albetebsy

Journal Of The Faculty Of Arts- Mansoura University

$50^{\text {th }}$ ISSUE- Jan.2012 


\title{
SAM SHEPARD'S THE GOD OF HELL AN ECOCRITICAL READING OF A PLAY ESSENTIALLY POLITICAL
}

\author{
Dr. Abdullah Albetebsy
}

Sam Shepard (1943-- ) is one of America's most celebrated dramatists who has written nearly 50 plays and has seen his work produced across America. His plays are regularly anthologized and taught by theatre professors as productions of a canonical American author. He has also achieved fame as an actor, writer, and director in the film industry. With a career that now covers nearly forty years, Sam Shepard has gained the critical regard, media attention, and iconic status enjoyed by only a few in American theatre. Throughout his career, Shepard has accrued numerous grants, prizes, fellowships, and awards, including the 'Cannes Palme d'Or' and the 'Pulitzer Prize'. He has received abundant popular praise and critical appreciation. While the assessment of Shepard's standing may indicate occasional exaggeration, there can be little doubt that he has spoken in a compelling way to American theatre audiences, and that his plays have deeply resounded in American culture.

Shepard's play The God of Hell (2004), may have been written with the intention of influencing 2004's American elections. It was described by Shepard as "a takeoff on Republican fascism, in a way". He added that he thought it would be more significant if seen during the presidential campaign: "I kind of wanted to get it done in New York before the election," he said, adding somewhat sheepishly, "I'm not sure it matters, but I figured I'd get it out there" (qtd. in McKinley). Robert Brustein asserts that the play was the first strong account of the rightward drift of America under George W. Bush. He also observes:

Shepard, preoccupied of late with family dramas such as Buried Child, The Curse of the Starving Class, and his most recent work, The Late Henry Moss, has been galvanized by current events to write his most overtly political play since States of Shock (1991). (Brustein)

According to Konistantinos Blatanis, the play " aims at capturing in stage images the feeling of bewilderment prevalent in post-9/11 America, where the appropriation of the national by a newly-conceived 
type of order is attempted via directed attacks on the people's understanding" (106). The God of Hell was described by Billington as a "blunt-edged attack on the Bush regime"; however, it has been justified by subsequent events such as Abu Ghraib, the growing power of agribusiness and the development of 'mini-nukes' (Guardian, Theatre. 1).

In spite of elapsed time and the Republican victory in those elections, the play has not only presumed a more general social relevance but it still has the power to amuse as well as disturb. "The most rewarding piece of theatre," writes Bracco, "is one that stimulates thought, opens dialogue, and leaves people talking about the play for hours, days, even years later" (Bracco, 2009). Indeed, great playwrights such as Shakespeare, Bertolt Brecht, Arthur Miller wrote plays that jarred audiences. The God of Hell combines the author's view of the facts of human idiosyncrasy with a more serious message where Shepard investigates patriotism, compromised or rather violated democratic values and the threat of unscrupulous nuclear research. Karen Weinstein assures that,

. . . none of [these] issues has lost its currency in the intervening . . . years. If anything, threats to American freedoms seem more numerous and the government less responsive. The graphic portrayal of torture reflects television footage from Abu Ghraib as well as stories about Guantanamo. Personal privacy has continued to be under the flag of patriotism and fighting the 'enemy'. (Weinstein)

The God of Hell is set in a Wisconsin dairy farm where the heiferbreeding Frank and Emma live in rustic isolation. The sound of bellowing cows gives a background atmosphere to the homely domestic scene. "Kitsch floral carpet ... and a multitude of houseplants populate the stage" (Loveridge). Their peace has been devastated by Graig Haynes, a radioactive runaway from a plutonium-producing establishment. While he hides in the basement, a supposed salesman of patriotic paraphernalia, named Welch, turns up in hot pursuit of him. The rest of the play is a process of bullying in which Welch, not only gets his man but also terrifies the innocent couple. 
The title of the play is derived from 'Pluto'-- the Greek "god of departed spirits and of the underworld (Hades)". Plutonium is "an artificial metallic element . . . having up to 15 isotopes . . . the most important of these isotopes is $\mathrm{Pu} 239$, which can be produced in large amounts in nuclear reactors . . . [and] forms uranium 235. It is used as nuclear fuel and as a nuclear explosive ... "(The New Lexicon Webster's Dictionary of the Eng. Language Ency. Edition). Although it occurs in trace amounts in nature, it is a nasty stuff that can linger in the environment for "five hundred thousand years . . . the most carcinogenic substance known to man ... It causes mutations in the genes of the reproductive cells", as Graig Haynes informs his hosts (The God of Hell, 41). In short, it poses a lethal threat to natural life cycles in all its manifestations symbolically embodied in the dairy farm.

Stimulated by the argument above, especially the part related to the title of the play and the fatal environmental hazards to life generated by faulty handling of radioactive elements, this study is intended to analyze The God of Hell from an eco-critical perspective, thus moving beyond the common political reading of the play to a more advanced discussion of the eco-human relationship with view to highlighting contemporary ecological issues so that current environmental problems may be addressed properly and more urgently. However, the political aspect cannot be totally ignored simply because politics is so much a part of the way we experience our lives - from the communities we live in to the food we eat, to the way we are educated, and to the resources we do or do not have access to. It only makes sense that the stories onstage reflect these realities. Bracco observes that "political artists . . . are choosing to create and present stories that ask tough questions about the world around us. By doing so, they are serving their communities" (Bracco, 2009). Therefore, ecological aspects in the play will be underscored as much as possible, especially when in interplay with other elements - dramatic, political, social, economic . . . etc. Nonetheless, an introduction to eco-criticism-its concept, techniques and devices seems to be necessary before examining the play.

Ecocriticism is the study of the relationship between literature and the natural environment. It was officially introduced by the publication of two germinal works, both published in 1996: The Ecocriticism Reader, edited by Cheryll Glotfelty and Harold Fromm, and The Environmental Imagination, by Lawrence Buell. Glotfelty defines ecocriticism as "the 
study of the relationship between literature and the physical environment" (xviii). Buell defines it as a "study of the relationship between literature and the environment conducted in a spirit of commitment to environmentalist praxis" (430). In an article that extends ecocriticism to Shakespearean studies Simon Estok argues that it is more than simply the study of Nature or natural stuff in literature; rather, it is any theory that is committed to effecting change through:

analyzing the function-- thematic, artistic, social, historical, ideological, theoretical, or otherwise-of the natural environment, or aspects of it, represented in documents (literary or other) that contribute to material practices in material worlds. ("Shakespeare and Ecocriticism" 16-17)

This echoes the functional approach of the cultural ecology branch of ecocriticism, which analyzes the analogies between ecosystems and imaginative texts and assumptions that such texts potentially have an ecological function in the cultural system (Zapf, "Literary Ecology"). Estok also notes that ecocriticism has distinguished itself by the "ethical stand it takes, its commitment to the natural world" as an important thing rather than simply as an object of thematic study, and "secondly by commitment to making connections" ("A Report Card on Ecocriticism," 220). Camilo Gomides has offered an operational definition that is both broad and discriminating :"The field of enquiry that analyzes and promotes works of art which raise moral questions about human interactions with nature, while also motivating audiences to live within a limit that will be binding over generations" (16). Ecocriticism can be further distinguished from other critical approaches. While literary theory, in general, examines the relations between writers, texts and the world which is almost synonymous with 'society' or the 'social sphere', ecocriticism expands the conception of the world to include the whole ecosphere.

Ecocritics pose questions about the role of the landscape; whether the underlying values of the text are ecologically sound or not; what is meant by nature; what nature writing is; if the examination of place should be a distinctive category like class, gender and race; what our perception of wilderness is and how it has varied throughout history; if current environmental issues are accurately represented or at least 
mentioned in popular culture and modern literature; whether the principles of ecology can be applied to poetry; if gender affects the way one perceives and writes about nature; how corporations, government officials, advertising executives and hosts of televised nature shows differ in their perceptions, reactions and approaches to their respective views of nature; and finally, what other disciplines such as history, philosophy, ethics and psychology can contribute to ecocriticism. William Rueckert may be the first to use the term "ecocriticism" in his essay " Literature and Ecology: An Experiment in Ecocriticism" (1978), where his intention is to focus on "the application of ecology and ecological concepts to the study of literature" (Reprinted in Glotfelty 107).

Writers have unintentionally been doing ecocriticism for centuries before the genre burst forth onto the academic scene in the early 1990s. "From Virgil's Georgics to John Clare to Thoreau to Rachel Carson," remarks Harold Fromm, "sensitive people had actually noticed that they were living on and from the primal mud of Earth" ("Ecocriticism's Big Bang ..." 1).

Interested individuals and scholars have been publishing works of ecotheory and criticism since the late 1960s and 1970s. However, such works were scattered and classified under different subject headings such as pastoralism, human ecology, regionalism, American studies, and so on. In the mid-eighties scholars began to work collectively to establish ecocriticism as a genre, primarily through the work of the Western Literature Association in 1991. The early years of ecocriticism brought together contemporary nature writers, admiring critics of classic nature writers, and academics interested in, and frenzied by, growing problems of air pollution and environmental degradation. "Since the birth of Asle [Association for the study of Literature and Environment, 1991], comments Fromm, "the ecocritical net has cast over wider and wider territory to include the ecology of cities, environmental racism, environmental law, capitalism, colonial exploitation and much more" ("Ecocriticism's Big Bang...." 1).

In his "Consilience, Ecocriticism, and Ecological Destruction," Hoeg further explains that ecocriticism offers the possibility of a "consilient criticism, that is, one that unites the sciences and the 
humanities in a continuum of knowledge". He adds that consilience means that "the various branches of knowledge support each other to form a unified whole . . . and none contradicts the other" (2). The basis of this 'consilience' is rooted in the close relationship between man and environment. In a very interesting paradoxical statement on this relationship, Fromm declares that there is nothing as "the environment" that "surrounds" human beings who are only made of some special substance that can be distinguished from the "surroundings". $\mathrm{He}$ concludes that, "there is only one congeries of earthly substance and it comprises everything from eukaryotes to Albert Einstein. . . . There is no environment, only an ensemble of elements recycled through every existing thing" (2).

Advocates of ecocritical theories argue that we are living in a post-human world in which the absolute boundaries between humans and non-humans, as well as between nature and society, have been broken down and all beings are connected together in a series of overlapping "webs" or "networks" of activity (Jacques, 2007). This explains why the boundaries of ecocriticism continue to expand to include all environmental components and their relationship with human beings.

Regardless of the broad scope of inquiry, and varying levels of complexity, resulting from the underlining unity of life, all ecological criticism shares the basic principle that human culture is closely connected to the physical world. However, ecocriticism takes as its subject the interconnections between nature and culture, especially the cultural artifact of language and literature. Moreover, there has been relatively little dispute about the moral and philosophical aims of ecocriticism, although its scope has broadened rapidly from nature writing, Romantic poetry and canonical literature to take in film, TV, theatre, animal stories, architectures, scientific narratives and an extraordinary range of literary texts. (Ecocriticism.encyclo.topics/ reference.com)

It is noteworthy of Shepard's theatrical world that the surrounding external elements are always threatening and potentially dangerous to the commonplace safety of domestic life, which causes in most instances, the inhabitants of the dwelling to discover that they are not so safe with each other, either. Therefore, fear, deception, moral compromise, misperception, and lack of communication characterize the relationships 
in most of Shepard's work. These aspects stimulate and describe not only his view of the Bush administration, and the nature of governmental intrusion with a Wisconsin dairy farm couple and their two uninvited guests in The God of Hell, but also the serious environmental risks endanger the American people.

In the same vein, it might be ecocritically significant that "Of all the contemporary American playwrights," as John Lahr observes, "Shepard has the deepest connection to the romance of the land, and a sense of the sin that comes with it" ("Shadowboxing; The Theatre"). The setting of The God of Hell is one of those Midwestern farmhouses familiar to theatregoers from True West and A Fool for Love. The play centres on the typical Shepard figures of a humble farmer and his wife, Frank and Emma, a politically out-of-touch farming couple who are among the last holdouts in an area where independent dairy farmers are being pushed out of business. Nonetheless, they are about to have their world rocked out of complacency. Here, the vast plains stand out as an antidote to selfish urban capitalism.

Reticent Frank is seen oiling his boots and murmuring about feeding the heifers while Emma hangs around the kitchen burning bacon and over-watering her plants. Soon after they agree to put up Frank's old friend Haynes, who is on the lam from a secret government project involving plutonium, they are visited by Welch, a creepy government bureaucrat, who is described as "an energetic devil disguised as a businessman who moves in with an American-flag cookies as his calling card" ("PATRIOT ACTS). His aggressiveness puts Frank, Emma and Haynes "on the defensive, transforming a heartland American household into a scene of torture and conformity for conformity's sake" (Goldstar).

While the action of the play is preposterous, a steady rip current of upsetting "references to torture, beheadings, and contamination accumulates, making the play darker, stranger, and more political than anything Shepard has written in years, possibly ever" ("PATRIOT ACTS"). David Rooney also remarks, in his review of the play, that "Shepard cooks up a nightmarish scenario that touches [among other things] on environmental disasters, corporatization of farming and political coercion. The playwright also throws in scenes of grotesque torture that explicitly reference Abu Ghraib" (Rooney). 
Eco-critically speaking, from the very beginning of The God of $\mathrm{Hell}$, there is a spotlight on the human-nonhuman relationship between the farm owners, Frank and Emma, and elements of their natural environment, especially animals and plants. It is a binding relationship of coexistence and interdependence. Welch, the government agent, remarks that he has seen Frank "down below in the barn. . . Mumbling to the cows. Riding around on the tractor like a little boy. A child of the plains (God of Hell, 11). Frank shows masculine strength as a result of physical labor. Indeed, living in nature is connected with power, health and happiness or at least contentment. Frank speaks softly to his heifers as if they were family members or close friends. Leslie Irvine believes that we develop a sense of self in relation to animals, and that to participate in the process of self-creation, animals, too, have selves which enable them to participate in relationships with us. These relationships, in turn, keep up, strengthen and sustain selves (Irvine 2). The phrase "graining the heifers" is repeated over and over again in the play. Frank is always feeding the heifers, and seems very devoted to them. He loves them and lives for them. In short, "it's his life's work" (45). He would not notice anything when he is with the cows which he describes as his "babies":

FRANK: I was feeding my heifers. I didn't notice what cars they were or if their antennas were bowed over.

: When I'm feeding the heifers, time stands still for me. Nothing else exists. (29-30)

HAYNES: Are those your cows down there?

FRANK: Those are my babies. .. . etc. (39-40)

Shepard seems to advance more or less the same argument as that outlined by Jamieson when he stresses the similarity between animals and humans:

They [animals] are conscious beings capable of enjoying life or experiencing pain and suffering. Both share the ability for 
suffering. Animals are innocent. They have done nothing to deserve human mistreatment or cruelty. Treating animals well helps create a more benevolent society, whereas cruelty and abuse lead to moral bankruptcy. (149)

Frank does his work around the farm in high spirits like a 'child of the plains'. He is so committed to his work that Welch is reluctant to interrupt him:

WELCH: No! No need for that. I wouldn't want to take him away from his chores. Good to see a man carrying out simple, traditional farm chores these days, without complaint.(15)

The farm, with whatever exists on it has become part and parcel of Frank's life. He can thus be perceived, as Slovic argues, "in . . relation to the natural world" in a way which establishes "the idea of kinship to the nonhuman world" (Slovic 26). This relationship between man and the environment is one of interrelatedness, since man is considered to be an integral part of the ecosystem (Evernden 93).

The essence of the ecological theory is man's identification with animals, which helps humans experience the sufferings of animals. This will lead in a sense to the prevention of animal maltreatment by humans. Malamud observes, "to come close, to understand that animals' lives are intermingled with our own and that our prosperity is ultimately interdependent on theirs. We are all in this together" (15). Besides, one principle of ecocriticism is to disclose how animals are cruelly treated at the hands of humans. This explains why Frank is so worried about what is going to happen to his heifers; first, when Haynes tells him about the effect of radiation, he exclaims if it would probably affect his heifers, to which Haynes responds, "Yes, it would Frank. It definitely would affect your heifers. It would affect every heifer within six hundred miles of here" (42). Later in the play, Frank is deeply upset when he learns that the cows will be taken to a wild, desolate place:

FRANK: Rocky Buttes? I thought you told me they were going to be air-dropped into exotic foreign lands. Palm trees! Desert oasis! Parachutes floating! 
: You told me my heifers were going to be glorified. Heroic. (94)

WELCH: You're going to like Rocky Buttes, Frank. Whole different landscape. Wide open. Just like the Wild, Wild West. Not a tree in sight. Endlessly flat and lifeless.

FRANK: Have they got any pasture out there, Graig?

HAYNES: Buffalo grass. That's about it.

FRANK: How are we going to feed my heifers?

Ecocritically, the nature of our relationship with animals and the way we regard them depend, to a great extent, on how we see ourselves and our place in the pattern of existence. This explains the difference between Frank's and Welch's ways of treating the cows; Frank sees them as vital and essential to his life while Welch would not care what would happen to them. Manning expresses "conviction that this diversity of attitudes and the paradoxes which it presents are not only of great intrinsic interest, its investigation is a necessary base from which to develop a sensible, yet sensitive approach to animals in the modern world" (Manning xi).

The play calls implicitly, through its satiric style, for a more humane treatment of animals and tries to provoke a human feeling of compassion and responsibility for these helpless inarticulate creatures. Thus, it brings a major contemporary ecological issue to public attention, consequently providing a new vision of an ecocritical understanding of the human-animal relationship. This would, hopefully, lead first to an increase of "sensitivity to animal suffering among the educated public, secondly to [a] discussion about the nature of animals and their relationship to man and thirdly to [a] preoccupation with the consequences of cruelty to animals for man's moral standards" (Maehle $50)$.

Not long after, this kinship, this time with plants, is further stressed in the conversation between Welch and Emma:

WELCH: What's that dripping sound? 
EMMA: Oh, I just watered the plants. They're dripping.

WELCH: I see. You have some sort of empathy with plants, I suppose.

EMMA: I like them, yes. Especially through the winter.(20)

She asserts, "If I ---if I didn't water like this, I wouldn't know what to do with myself. There would be a horrible gap. I might fall in" (50). It is an indissoluble psychological relationship of affinity, understanding, sympathy and compassion. This is very cleverly expressed as Emma objects to Welch, "Gas? You're not bringing smoke and gas into my home! My plants can't take it", when Welch threatens to force Haynes out of the basement by means of gas or smoke (65). To her, home plants are not just décor items; they play such an essential role in her life that she wouldn't know what to do without them, especially as she lives in rustic isolation with her husband in Wisconsin where "nothing ever happens. ... . People have been coming here for a hundred years because nothing ever happens" (48). These plants provide company to Emma where she would only see "the mailman now and then. The propane delivery truck. The driver," who would wave to them, but they "never talk to anyone" (54). Yet, Welch's reaction reveals, once more, how he wouldn't care about Emma's plants exactly as he has done with Frank's cows:

WELCh: Emma, maybe you could clean the place up a bit. Get these plants out of here before the meeting.

I've got all my people coming, Emma. What are they going to think about our readiness? We've got to get the place cleaned up. (96)

Nor is it surprising that an official like him tries to persuade Frank to go to the 'Rocky Buttes' region, by saying it is wild open "Just like the Wild, Wild West. Not a tree in sight. Endlessly flat and lifeless" (97). This clearly betrays the official negative, or at least careless, attitude towards environment. 
However hard the couple's living conditions are, they express contentment with their peaceful life in the country as dairy farmers; Emma observes, "I'm perfectly happy out here" (81), and that her husband has always been "very content in the country. Farming. Animal husbandry, hybrid vigor. Stuff like that" (46). Weinstein comments that, "it is a labor of love or perhaps of habit", which does not make any difference; Emma considers it to be really fine and that Wisconsin is a perfect retreat; Frank tells Haynes, "There's no tension here. We're in the country here. Everything's quiet and peaceful," and reiterates before long, "We lead a very peaceful life here. We're in the country. We're dairy farmers" $(37,39)$. From an ecocritical point of view, living in nature is connected with power, health and happiness or at least contentment; therefore, Emma and Frank would not leave their farm; actually there is no reason for that. Emma was "born and raised in the same house, still living in the same place. Same spot". People there would leave their doors open: "because this is Wisconsin. . . . It's not a custom, it's trust" (God of Hell. 50, 62).

Everything goes well till the couple's peace is shattered by two outside factors when Welch, a cruel desensitised government agent turns up in pursuit of Haynes, a fugitive victim of nuclear research. They represent two destabilizing forces-- politics and nuclear technology which collaborate to destroy the peaceful type of life Frank and Emma are leading. Welch stands for the right-wing Bush administration which was "intent on imposing rigid ideology disguised as patriotism and concern for national security" (Rooney, 2004). In response to this imposed fake patriotism, Shepard objects:

We're being sold a brand new idea of patriotism. It never occurred to me that patriotism had to be advertised. Patriotism is something you deeply felt. You didn't have to wear it on your lapel or show it in your window or on a bumper sticker. That kind of patriotism does not appeal to me at all. (The Village Voice)

Welch strides into the house as if he owns it, pushing American flag cookies and patriotic decor kits, and displaying a keen curiosity about the couple's basement, where the suspect fugitive is hiding. "Soon, the farm's simple, steady existence is endangered by these two incomers 
and their links to some top secret nuclear project," remarks Loveridge (2).

Total negative change that overcomes the whole place with its human inhabitants, animals and plants, is so drastic that Emma very worriedly exclaims, "Frank, the whole world can't just suddenly get turned inside out like this overnight" (87). Frank and Emma get into a state of uncertainty, fear, anxiety and apprehension. Governmental intervention has already had its serious impact on "The Heartland", "America's Dairyland" that has "all moved away ... The milk [and] the cows". When Welch comments, "But you've got cows down there", Emma replies, "There's just a few of us left". Most "dairy people" moved away "out west", because of "Agribusiness. Big corporations" (The play, 14-15). Later on, it is also repeated that nobody farms anymore because the Government pays them not to. Frank expresses his sorrow for becoming "vulnerable", "out here in the boondocks. Sitting ducks for solicitors", and for the fact that, "There's salesmen everywhere. Every time you turn around there's another salesman. Whole country's made of salesmen" (36). Indeed, this statement recalls Miller's play, Death of a Salesman or its title at least. However, it is here 'death of a dairy farmer'. Yet, what is meant at this time is rather spiritual death. Moreover, it is an outright criticism of the American economic system which publicly advocates and encourages small and even tiny projects, but in actuality, hinders them by supporting 'big corporations', instead.

It is now suspicious what Welch is doing in the heifers' pen:

HAYNES: Looks like he's walking around with your heifers.

FRANK: In the pen? He's in the pen with my heifers?

HAYNES: Looks like. Isn't he right inside there with them?

FRANK: I'll be right back.

HAYNES: Be careful, Frank. You don't know this guy. (43)

It is understood that he might be looking for Haynes; yet, nothing on the farm will escape the awful consequences of this hunt-- the house, the people, the heifers and the plants. Frank and Emma finally have to conform to Welch's or rather the government's deceptive way of looking at things. They have to follow the fake official type of 'patriotism' they do not believe in. 
Welch, uninvited and in a very grotesque manner, breaks into the house, "quickly closing the door behind him ... with American flag pin in his lapel, short cropped hair, crisp white shirt, red tie, attaché case in one hand and the cookie in the other. Big grin" (10). He persistently imposes his cookies and 'patriotic' baubles on Emma, who is apparently not interested. He goes so far to express suspicion about her husband who, according to Welch, "could fool somebody. . . . He could be one of those middle Europeans or something. Latvian maybe. Belarusian". Emma retorts, "I think you must have the wrong house or something. I don't know what in the world---" (12). Welch acts so evasively that Emma does not know what to do with him. "Well, I'm not really allowed to reveal my affiliations," he claims, "Let's just say we're on a kind of a talent search for solid citizens who own their own land outright. Are you sure you're not interested in a cookie?" (16). He also bullies Emma and Frank so as to get hold of their guest, Haynes:

WELCH: I couldn't help noticing your flagpole out front.

EMMA: WHAT ABOUT IT?

WELCH: (turning to her with a smile) It's empty. Barren. Just the raw wind slapping the naked ropes around. Sickening sound.

EMMA: So what?

WELCH: Well, Emma, this is Wisconsin, isn't it? I'm not in Bulgaria or Turkistan or somewhere lost in the Balkans. I'm in Wisconsin. Taxidermy and cheese! Part of the U.S. of A. You told me that yourself.

WELCH: You'd think there would be a flag up or something to that effect. Some sign. Some indication of loyalty and pride.

EMMA: Loyalty? To Wisconsin?

WELCH: (pacing through room) Nothing in here either. Not even one small token in the home. No miniature 
Mount Rushmore, Statue of Liberty, no weeping bald eagles clutching arrows. Nothing like that. We could be anywhere.

EMMA: We're not anywhere.

WELCH: Well, you and I know that, Emma, but what about the rest of the world? What about the people driving by-Everyday Joes? Wouldn't they like to look up here and be reminded of their proud heritage? (19-20)

Emma gets so confused about Welch that she yells at him: "Who are you, anyway? What is your name? What are you doing in my house?" When he snaps his case shut and abruptly goes out, "(She runs out on the porch and rings the ... bell for Frank across the frozen field.) Frank!! Frank!! Come on up here, would ya, Frank!" (22, 23). Emma tries to get rid of him. When he comes back to ask some more questions, she responds, "No! No more questions! You just get away from here . . .," but he, once more, "opens door and steps right in, closing door behind him." Emma yells:

Don't! Don't you dare come in here! What're you doing!?

You can't just come busting into people's houses like this. Who do you think you are? $(60,61)$

Then, he threatens he would use "high-priority tactics" to capture the fugitive:

WELCH: You know we are very, very skilled at flushing rats out from their nests. We've had vast experience. You wouldn't want to see a bunker buster come blasting into your little kitchen from heaven knows where, would you? Because we can arrange that Emma. It's just a phone call away. (64)

Welch escalates his threatening tone by saying he could use smoke or gas or that they: 
. . could flood him [Haynes] out, I suppose. Takes a little longer, but just as effective. There's always fire, but then we'd be losing the house, wouldn't we?

The political situation is so serious and the danger to democracy is truly menacing. Shepard skilfully phrases it out through Welch:

We can do whatever we want .... We're in the driver's seat. Haven't you noticed? . . . We're in absolute command now. We don't have to answer to a soul, least of all a couple of Wisconsin dairy farmers. (70)

Although Frank and Emma are among the very few dairy farmers holding out in the area, they are actually targeted for involuntary evacuation. Evasive and deceitful ways are followed by Welch to force it down on them. Brustein describes the way Welch takes over the house, turning it into what he calls a "Think Tank" for the government, to be "the spine of the play" (Brustein). He offers them promises of the "bright, golden American future that is waiting for them-when they leave the farm. He pretends to be sorry for them as they have been "living completely in the long ago. Stuck in some quaint pioneer morality" (71). Not long after, "Frank enters . . . dressed in suit and tie exactly like Welch's and carrying an attaché case exactly like Welch's. He walks very bowlegged and sore as something terrible has happened to his genetalia". Emma, terribly alarmed by this, asks him, "What happened to you? What's the matter?" (74). He answers that he has sold his cows to Welch at a very good price. Emma's comment on this concludes the whole situation: "This guy [the government] is taking over our house! He's taking over our whole life! Stringing up flags! Forcing cookies on me! Who is this guy? We don't know him from Adam!" (79). But, Frank has been subjected to a process of intimidation and brain wash, for he now airs ideas completely opposite to what he used to say:

FRANK: You don't want to hear about it, do you, Emma? You'd much rather go on thinking it's just the two of us, lost out here in an ocean of snow and ice. Milk and cheese. One monotonous frozen day after another. (81)

He goes so far as to accuse his friend Haynes of being a traitor who has betrayed them, a deceptive pretender who looks like them yet is deadly 
underneath."He is no compadre of mine. He's a two-faced, camel-loving--," yells Frank (91), who now ironically considers Welch to be a righteous man who "knows more than us. He's smarter than us. He knows the big picture . . . He's got a plan" (80). Thus, politics is portrayed as a very dangerous force that would shamelessly reverse facts, bluntly beautify vices and terribly corrupt personal relationships. Here is a pitiful example of sheer lying and total falsification:

(The sounds of heavy, labored breathing, feet scraping against the basement staircase; a low moaning comes from basement. Emma and Frank stare in that direction. Slowly, WELCH appears in shirtsleeves coming up the stairs backward, pulling on a long black cord apparently tied to something heavy at the bottom of the stairs.)

WELCH: (breathing heavily, pulling on cord) This is what we're up against now, Frank. Lying, deception, manipulating the truth! Right here in your own home. Right down in your own basement! A man who claims to be your friend. An ally. Can you believe it? There he was, hovering down there in a corner, plotting your annihilation. I finally got it out of him. Got to the nasty rock bottom of it. (87)

When Emma accuses him of torturing Haynes, Welch resumes his blatant, vain lying:

Torturing? Torturing! We're not in a third world nation here, Emma. This isn't some dark corner of the Congo. Frank, haven't you told her about our new platform? Our design for the new century? (87)

Then he (punches a button attached to the black cord. Haynes yells out in pain from below. Emma runs to top of stairs and looks down). Welch goes on bullying the couple:

She needs to get on the same page. Stop acting like some whacked-out subversive. You've explained the dangers to her, haven't you? Frank? The folly of mixed messages? 
Well, we've got to get her involved, Frank. She can't be flopping around on the outside of the loop, like a fish outa water. It's too risky. (88-89)

Frank is also led to believe that when he gives up his heifers, which are actually the source of happiness to him and his wife, they will contribute to the future security of the American nation!; therefore, they are "going to be glorified," but he fails to explain how, when Emma wonders how heifers can contribute to the national security!

FRANK: You'll see. It's all going to be revealed at the meeting. You're going to be very proud of those heifers, Emma. I guarantee you.(84)

Very shortly after, he discovers the trick; his cows will be dumped in an out-of-place, wild, rocky desert area, endlessly flat and lifeless, where there is not even a single tree in sight:

FRANK: Rocky Buttes? I thought you told me they were going to be air-dropped into exotic foreign lands. That's what you said. Palm trees! Dessert oasis! Parachutes floating!

You told me my heifers were going to be glorified. Heroic!

WELCH: you've got to drop all that now, Frank. Leave the simple past behind. We've got to get a move on here. We're dealing with a ruthless, diabolical, treacherous, despicable force. What's the matter with you people? Don't you get it?

FRANK: No, this isn't what I had in mind. You painted me a different picture. (coming down off sofa, tries to hand case[containing money] to WELCH) Here you take this money back. I don't want it. (94, 95)

Radioactive contamination is another serious ecological issue that is essentially an ecocritical concern. Although it is apparently not the "bushy target evoked by the title of Sam Shepard's . . p play," (Feingold) radioactive contamination is a very serious environmental hazard. It 
poses horrible dangers to anything that has life in it-man, animal or plant. Plutonium is mentioned in the play as an example. It is so terribly perilous that Haynes suggests it is named after "Pluto, the god of hell". It "remains radioactive and biologically dangerous once it is released into the atmosphere, "for five hundred thousand years. Moreover, it is "The most carcinogenic substance known to man. It causes mutations in the genes of the reproductive cells. The eggs and the sperm. Major mutations. A kind of random compulsory genetic engineering that goes on and on and on". Its impact is so far reaching that it would affect everything within "six hundred miles". It is also so inexorable that it "would penetrate the food chain and bio- accumulate thousands of times over, lasting generation after generation. Tasteless, odorless, and invisible" (The play, 42).

This directly recalls what happened to Hiroshima and Nagasaki, the two Japanese cities that were almost totally destroyed by US atomic bombs during the Second World War. In Hiroshima only the bombing directly killed "an estimated 80,000 people. By the end of the year, injury and radiation brought total casualties to $90,000-140,000$. Approximately $69 \%$ of the city's buildings were completely destroyed, and another $7 \%$ severely damaged (Radiation Effects Research Foundation 2011). Nor will one forget the horrendous effect of atomic radiation on man, animal and plant life, that could be seen everywhere in Japan a long time after the war.

Another terrible accident, that would never be forgotten, occurred in April 1986, at the Chernobyl Nuclear Power Plant near Kiev in the Ukrainian Republic of the Former Soviet Union. With the release of radiation, human casualties, physical damage to the plant and contamination of the surrounding environment, Chernobyl marked the worst accident in the history of nuclear power production. The Chernobyl reactor was designed to produce "weapons grade plutonium and to generate electricity at the same time". According to Howard Shaffer, from The American Nuclear Society,

The accident released a cloud of radioactive particles and gases that created measurable increases in doses in the Northern Hemisphere. Doses were highest in European countries .... The lack of clear information and different standards in each country created panic in Europe. Many 
livestock were ... destroyed and food wasted, while exposed food was consumed in Soviet republics. (Shaffer)

The World Health Organization has reported that the accident led to:

the fatalities of thirty-six workers. More than 200,000 people in the Ukraine and Belarus Republics were evacuated and resettled as a result of significant fallout from the Chernobyl accident. (In http://www.new.ans.org/pi/resources/ sptopics/ chernobyl)

Land contamination was reported not only in the Ukraine Republic, Belarus Republic, Russia, but also in Europe, and Scandinavia.

The most recent nuclear accident occurred in Japan on March $11^{\text {th }}$, 2011, following a major earthquake resulting in a 15--metre tsunami, which disabled the power supply and cooling of three 'Fukushima Daiichi' reactors. Major releases of radiation, including longlived types, occurred to air. Moreover, a large amount of contaminated water had accumulated on site and some radioactivity has been released to the sea. Six workers have received radiation doses over the level set by NISA (Nuclear and Industrial Safety Agency). Although there have been no harmful effects from radiation on local people, nor any doses approaching harmful levels, some 160,000 people were evacuated from their homes and are allowed limited return in 2012. (See World Nuclear Association."Fukushima Accident 2011").

In The God of Hell, Haynes, who is a scientific researcher, is first introduced as a getaway old friend who arrives in the Wisconsin home of the loving farm couple to stay for a while. It is later made known that he is a fugitive on the lam from some unnamed dread, revealed afterwards to be secret nuclear experiments. He is in a pathetic condition, for if he touches or is touched by anyone or anything, he emits electric sparks in the form of a bright blue flash of light, which he describes as a static shock. But Emma comments that she has "never seen anything quite like that. I mean, I've had static shock before, but — rugs and doorknobs and stuff, but - " (31). The cause is understood to be the radiation he has been exposed to:

WELCH: I'm afraid you have to [go back] now. You're contaminated. You're a carrier. What're we going to do about that now? We can't have you free- 
ranging all over the American countryside like some kind of heedless chicken, can we? You've already endangered the lives of your friends, not to mention the Midwest at large. Now, that was pretty selfish of you, wasn't it? Poisoning the Heartland? (68)

However, Haynes does not want to go back. It seems the situation is too serious; "the whole state's going to explode. Colorado is going to be blown off the map." Welch ridicules him:

WELCH: Why do you people have this incredible propensity for wild exaggeration? There's some minor leakage —we've acknowledged that. That's why you were hired in the first place, if you recall.

HAYNES: Minor leakage! (68)

WELCH: That's what it was. The concrete wasn't thick enough.

HAYNES: The ground caught fire for thirty days! Not trees, not brush, but the raw earth! (69)

In SCENE THREE, the stage direction reads: "(He [Frank] walks very bowlegged and sore as though something terrible has happened to his genitalia)" (77). He is in pain and when Emma touches him, he gives off a blue flash of light. He tells his wife not to touch him because he is contaminated. Now, the whole place seems to be contaminated. Even the "plants begin to emanate blue flashes, which increase in intensity..." (98).

Welch and his team go to the couple's house with one target - to take Haynes back to the nuclear facility from which he tries to run away. They chase him by following the radioactive traces he has in his body. When Haynes asks Welch how they tracked him down, he answers:

You left a very luminous trail, Mr. Haynes. Technology's a marvellous thing, though. Night vision. Infra-ray. It's extraordinary how blind the naked eye is. No wonder people have so much trouble accepting the truth these days. (67) 
But Haynes is resolute not to go back with him, on which Welch threatens they would have him go through a process of torture he has undergone before:

WELCH: Yes! Exactly. What would happen to your body if you had to undergo the same ordeal? The same stress to your appendages.

: The pain to your penis, for instance?

HAYNES: No!!! No!!

(HAYNES suddenly grabs his crotch with both hands and holds on. A bolt of blue light shoots from his crotch. HAYNES just stands here, frozen, holding on to his crotch and staring out towards audience. . .). (72-73)

They use very cruel and inhuman ways to force him to return to the nuclear facility. Welch drags Haynes up from the basement by an electrical cord tied to his penis. This manner of torture is reminiscent of that followed with the prisoners at Abu Ghraib, Iraq as well as Guantanamo:

(WELCH punches a button attached to the black cord. HAYNES yells out in pain from below. Emma runs to top of stairs and looks down.)

EMMA: Oh, my God! Frank! He's got him by the penis!

(A scream from HAYNES as WELCH hauls him to the top of the stairs and into the room. HAYNES comes crashing up, clutching the black cord with both hands. The cord runs directly into the fly of HAYNES'S pants. He stands there panting. Emma--- off to the side, horrified. Frank stays standing on couch, staring and clutching his crotch.) (89-90)

This scene also recalls Beckett's masterpiece, especially the scene where "Pozzo drives Lucky by means of a rope passed round his neck," and keeps jerking the rope while giving him orders as if Lucky were an animal (Waiting for Godot, 21). However cruel this manner of treatment is, Haynes is more cruelly dealt with like a senseless machine that can be reprogrammed and recoded. After being tortured, he tries to say 
something, but only utters unintelligible, mixed up words, phrases and sentences:

(on [sic] knees) This is that moment - that place in time. You remember - there were these -there are, now-history. This is it now. Where we move-where we-we must-seize the day. That's it! We must snap ourselves back into it. Grab ahold [sic]. Jump right in there and smash the holy shit out of them before they get any more smart-ass ideas. This is it! We must - don't you know that? Don't you know? (92)

Emma wonders what in the world Haynes is trying to say, to which Welch grotesquely replies, "He's just reprogramming, Emma. He'll be fine..." (92). Moreover, Frank is seen marching with Haynes trying to catch up with his steps. He acts like a robot mindlessly obeying orders, on which Emma grabs him while yelling: "Frank! Stop it now! This isn't you! This isn't who you are! Frank! What have they done to you!?" (96); however, Welch surprises her with a cynical rhetorical question of marked directness and clarity:

What did you expect? You didn't think you were going to get a free ride on the back of Democracy forever, did you? Well, did you? What have you done to deserve such rampant freedom? Such total lack of responsibility? (97)

Welch, very expertly, makes use of her utter bewilderment and commands her: "Now be a good girl ... . Get in step, Emma. Get in step" (98). He now engages her in an area she appears completely unskilled to deal with. Nevertheless, she resists as no one else does in the play, and she alone sees the danger Welch presents; indeed, he poses a dangerous threat to American freedom and personal privacy which continues to be under attack under a false banner of patriotism and a blown- up slogan of 'fighting the enemy'. "The playwright interrogates," according to Blatanis, " the legitimacy of this new policy of containment, along the parameters of which distinctions between friends and enemies, patriots and traitors, the invaded ones and the invaders are difficult to be drawn" (106).

This multi-facet contamination- environmental, social and political, stimulates Frank's nostalgia for past times: 
It's times like this you remember the world was perfect once. Absolutely perfect. Powder blue skies. Hawks circling over the bottom fields. The rich smell of fresh-cut alfalfa laying in lazy wind rows. The gentle bowling of spring calves calling to their mothers. I missed the COLD WAR so much. (91)

Thus, the play ends sounding a clamorous ecological alarm that was originally intended to be social and political, as Emma "goes outdoor, leaving it open, and starts ringing the bell. She keeps ringing as the lights fade. As lights get dimmer, the plants begin to emanate blue flashes, which increase in intensity as lights go to black. Music over. Bell continues" (97).

The play is properly open-ended; no denouement as such is provided to the audience. "Rather, this void and emptiness, created out of the haunting visual and auditory image of Emma ringing the bell," marks Konstantinos Blatanis, "serves to illustrate the playwright's conviction that what is more urgent than anything else is precisely" the provocation of the audience to pursue, on their own, "the types of interrogations highlighted throughout the play" (125).

To conclude, although The God of Hell is essentially a political play written mainly as a satire of the Bush Administration with view to the 2004 elections and the status of American democracy, with a domestic social background, it has subtle, yet obvious, ecocritical undertones. The human-nonhuman connection, now granted as an interrelated and interdependent relationship, is lightly but effectively touched upon. Moreover, the impact of contemporary politics, economics and modern technology on the environment, with its wide-range definition comprising human, animal and plant components, is dexterously explored.

From the very beginning, there are early signs of ecocritical significance, first in setting the play on a Wisconsin dairy farm -one of a few remaining farms in a region taken over by agribusiness. No one would, at first glance, miss the presence of basic ecological elements of nature, man and animal. There are "Frosty windows looking out to distant vague, snowbound pastures. . . . Many potted plants of various sizes," and Emma is seen filling a pitcher with water, carrying it to the plants, then repeating the process over and over again. She notably admits the necessity of these plants to her existence. Nature also seems 
to be associated with power, health and happiness or at least contentment. Frank shows manly strength as a result of interacting with the natural environment around him. He also speaks softly to his heifers in the barn, as if they were family members or close friends. $\mathrm{He}$ is always feeding them, loves them and lives for them. He is terribly worried about what is going to happen to these animals more than about what is going to happen to him or to his wife. In short, these heifers are part and parcel of his life. Thus, the human-nonhuman relationship between the farm owners, Frank and Emma, and their animals and plants is frequently stressed. It is a necessary relationship of coexistence and interdependence.This is brought in sharp contrast with the way Welch thinks of and reacts to these most important components of the environment.

Likewise, the play draws attention to another serious ecological issue that is essentially an ecocritical concern i.e. radioactive contamination. Indeed, it is a severe long-lasting environmental hazard that should be carefully addressed, or consequences would be devastating beyond all expectation. Plutonium is the example of radioactive elements given in the play; it is most dangerous once it is released into the atmosphere, the most carcinogenic substance known to man. It causes serious major changes in the genes of the reproductive cells. Its menace is inevitable and so far reaching that it would impinge on everything hundreds of miles away. It would also infiltrate the food chain, accumulate over and over, and would last for a very long time, which directly recalls Hiroshima and Nagasaki, and other instances of radioactive leakage from atomic and nuclear reactors in different parts of the world, the latest of which was that of the Fukushima power plant in Japan, September, 2011 (for more information about this incident, please go to United Press International, World News' site: http://www.upi.com/Top News/ World-News/2011/09/11).

Granting the idea that ecocriticism unites various disciplines in a 'continuum of knowledge', and that the various branches of knowledge support each other to form a unified whole, other forms of contamination, however figurative this may be, are brought under fire by Shepard. The God of Hell abounds in barefaced political and unethical instances where corrupt methods and tactics are used by Welch, who is actually a flagrant example of government officials. These include manipulation, lying, deception, shamelessly twisting or even reversing facts and bluntly 
beautifying vices. Welch would, nonetheless, spare no effort in using psychological and physical types of pressure while raising false banners of patriotism and blown-up slogans of 'fighting the enemy'. Likewise, he adopts a policy of repression, along the criteria of which it would be too difficult to distinguish between friends and enemies, loyalists and traitors, the occupied and the occupiers, thus terribly spoiling personal relationships. However, the vociferous bell Emma urgently rings at the end of the play is the playwright's continuous alarming outcry against all environmental, political, social and ethical violations highlighted throughout, so that his audiences may be provoked into positive awareness that would lead to addressing these abuses on their own. 


\section{Works Cited}

American Nuclear Society: (http://www.new.ans.org/pi/ resources/sptopics/chernobyl/). Last updated, December $15^{\text {th }}$, 2011.

Billington, Michael. "The God of Hell," Guardian, Theatre, Thursday 27 October 2005. In http://www.guardian.co.uk /culture/ 2005/ oct/27/ theatre.art1

Blatanis, Konstantinos. "Mediating Acts of War/Staging Crises of Sensibility: David Rabe's Sticks and Bones, Eve Ensler's Necessary Targets, and Sam Shepad's The God of Hell." In http://my.enl.auth.gr/gramma/gramma08/ blatanis.pdf. Last retrieved, March $22^{\text {nd }}, 2012$.

Bracco, Tara."The Power of Political Theatre," The Brooklyn Rail, Theater. July 17, 2009. In http://www.brook lynrail. org/

Brustein, Robert. "The Rebirth of Political Theater: on Theater: The God of Hell." New Republic; 12/20/2004, Vol. 231 Issue 25, p31-33, $3 \mathrm{p})$. In http://search.ebscohost.com /login.aspx?

Buell, Lawrence. The Environmental Imagination: Thoreau, Nature Writing and the formation of American Culture. Cambridge, MA and London, England: Harvard University Press, 1995.

Estok, Simon C. (2005) "Shakespeare and Ecocriticism: An Analysis of 'Home' and Power in King Lear." AUMLA 103 (May 2005): 1541.

"A Report Card on Ecocriticism." In http://www. asle.umn.edu/archive/intro/estok.html) AUMLA 96 (November):200-38.

Evernden, Neil. "Beyond Ecology." In Glotfelty and Fromm, 1996.

Feingold, Michael. "The God of Hell." The Village Voice, Theatre. 49(47):87. 30 ${ }^{\text {th }}$ Nov. 2004.

Fromm, Harold. "Ecocriticism's Big Bang: A Review of Practical Ecocriticism: Literature, Biology, and the Environment by Glen A. Love, in http://www.logosjournal.com/fromm.pdf. Summer, 2004.

Glotfelty, Cheryll and Harold Fromme(eds). The Ecocriticism Reader: Landmarks in Literary Ecology. Athens and London: University of Georgia, 1996. 
Goldstar, Los Angelos. July 23, 2006. In http://www.Goldstar. com/events/los-angelos-ca/the-god-of-hell

Gomides, Camilo. "Putting a New Definition of Ecocriticism to the Test: The Case of The Burning Season, a film(mal) Adaptation." ISLE 13.1 (2006):13-23.

Hoeg, Jerry. "Consilience, Ecocriticism, and Ecological destruction," April 29, 2010. In http://www. politicsandculture.org/ authors/jery-hoeg/

Irvine, Leslie. If You Tame Me: Understanding Our Connection With Animals. Philadelphia: Temple University Press, 2004.

Jamieson, Dale. Morality's Progress: Essays on Humans, Other Animals and the Rest of Nature. Oxford: Clarendon Press, 2002.

Lahr, John. "Shadowboxing; The Theatre." The New Yorker, 80(37): 161163. Nov. $29^{\text {th }}, 2004$. Last updated October $4^{\text {th }}, 2010$.

Loveridge, Charlotte. "Review," Curtain Up: the Internet Theater Magazine of Reviews, Features, Annotated Listings, October $26^{\text {th }}$, 2005. In http://www. curtainup. com/

Maehle, Andreas-Holger. "Literary Responses to Animal Experimentation in seventeenth and Eighteenth-Century Britain." Medical History, 1990 January; 34(1): 27-51.

Malamud, Randy. "Animated Animal Discourse." Chronicle of Higher Education 54(8):15.

Manning, Aubrey \&- James Serpell. Eds., Animals and Human Society: Changing Perspectives, New York: Routledge, 2002.

McKinley, JESSE. "Pointed New Shepard Play to Arrive Just Before Election," The New York Times-Theater: October 4, 2004. In http://www.nytimes.com/2004/10/04/theater/

Radiation Effects Research Foundation, " Frequently Asked Questions". In http://www.rerf.or.jp/general/qa_e/qa1. html/.Last retrieved July $29^{\text {th }}, 2011$.

Rooney, David. "The God of Hell." Variety Legit Reviews, Nov. 16, 2004. In http://www.variety.com/biography/1058

-."The God of Hell," Review. In http://www.variety. com/ review/. Last retrieved, Jan $19^{\text {th }}, 2012$.

Shafer, Howard. "Chernobyl in Brief," American Nuclear Society, December 27, 2005. In http://www.new.ans.org/ pi/resources/sptopics/chernobyl/ brief.php. Last retrieved April $19^{\text {th }}, 2012$. 
Shepard, Sam. The God of Hell. New York: Vintage Books, A Division of Random House, Inc. 2005.

-.PATRIOT ACTS: Back in New York with a new play and starring in another, Sam Shepard reflects on the dangerous farce of contemporary politics," The Village Voice, November 17, 2004. In http://donshewey.com/ theater articles/sam_shepard_vv.html

Slovic, Scott. "Giving Expression to Nature." Environment 41(1):25-32, 1999.

The New Lexicon Webster's Dictionary of the English Language.

Encyclopedic Edition. New York: Lexicon Publications, Inc. 1988.

United Press International, World News. "Japan atomic leak 3 times first estimate". In http://www.upi.com/World-News/2011/09/11.

Weinstein, Karen. "The God of Hell. Sam Shepard," July 2 ${ }^{\text {nd }}, 2006$. In http://www.ourstory.com.

World Nuclear Association."Fukushima Accident 2011". In http://www.world-nuclear.org/info/

fukushima_accident_inf129.html. Last updated, April $\mathbf{1 4}^{\text {th }}$, 2012.

Zapf, Hubert. "Literary Ecology and the Ethics of Texts." New Literary History 39.4(2008):847-868. 


\section{Sam Shepard's The God of Hell}

\section{An Ecocritical Reading of a Play Essentially Political}

(Summary)

This study is intended to analyze Sam Shepard's The God of Hell from an eco-critical perspective, thus moving beyond the common political reading of the play to a more developed discussion of the ecohuman relationship with view to highlighting contemporary ecological issues. However, the political aspect cannot be totally ignored simply because politics is so much a part of the way we experience our lives. Ecological aspects in the play are accentuated as much as possible, especially when in interaction with other elements - dramatic, political, social, economic .... etc. An introduction to eco-criticism-its concept, techniques and devices seems to be necessary before examining the play.

Ecocriticism can be simply defined as the study of the relationship between literature and natural environment. It is also argued that Ecocriticism is any theory that is committed to carrying out change through investigating the function of natural environment, or aspects of it that contribute to material practices in material spheres of life. Ecocritics pose various questions about the role of the landscape, the meaning of nature and nature writing, our perception of wilderness and how it has varied throughout history, whether the principles of ecology can be applied to literature, and finally, what other disciplines such as history, philosophy, ethics and psychology can contribute to ecocriticism.

Writers have unintentionally been doing ecocriticism for centuries before the genre burst forth onto the academic scene in the early 1990s. Interested scholars have been publishing works of ecotheory and criticism since the late 1960s and 1970s. In the mid-eighties they began to work collectively to establish ecocriticism as a genre, primarily through the work of the Western Literature Association in 1991.

Regardless of the broad scope of inquiry, and varying levels of complexity, all ecological criticism shares the basic principle that human culture is closely connected to the physical world. However, ecocriticism 
takes as its subject the interconnections between nature and culture, especially the cultural artifact of language and literature.

This research has been stimulated by the title of the play and the fatal environmental hazards to life generated by faulty handling of radioactive elements. The title (The God of Hell) is derived from 'Pluto'-the Greek god of the underworld (Hades), and Plutonium which is used as nuclear fuel and explosive that can hang on in the environment for as much time as five hundred thousand years. It is considered to be a highly carcinogenic that, at the same time, causes mutations in the genes of the reproductive cells. In short, it poses, in all its manifestations, lethal threats to natural life cycles symbolically represented by the dairy farm in the play.

Although The God of Hell is essentially a political play written mainly as a satire of the Bush Administration with view to the 2004 elections and the status of American democracy, from the very beginning of the play, there is focus on the human-nonhuman relationship between the farm owners, Frank and Emma, and elements of their natural environment.The human-nonhuman connection is lightly but effectively touched upon. Moreover, the impact of contemporary politics, economics and modern technology on the environment, is skilfully explored.

Early in the play, there are signs of ecocritical significance, first in setting the play on a Wisconsin dairy farm -one of a few remaining farms in a region taken over by agribusiness. No one would, at first glance, miss the presence of basic ecological elements of nature, man and animal. The human-nonhuman relationship between the farm owners, Frank and Emma, and their animals and plants is frequently stressed as a necessary relationship of coexistence and interdependence. This is brought in sharp contrast with the way Welch thinks of and reacts to these most important components of the environment.

The God of Hell calls, through its satiric style, for a more humane treatment of non-human elements and tries to provoke a human feeling of compassion and responsibility for these helpless inarticulate creatures. Thus, it brings a major contemporary ecological issue to public attention, consequently providing a new vision of an ecocritical understanding of the human-animal relationship 
Likewise, the play draws attention to another serious ecological issue i.e. radioactive contamination. Plutonium is the example of radioactive elements given in the play; it is most dangerous once it is released into the atmosphere, the most carcinogenic substance known to man, which directly recalls instances of radioactive leakage from atomic and nuclear reactors in different parts of the world.

Conceding the idea that ecocriticism unites various disciplines in a unified whole, other forms of contamination, however figurative this may be, are attacked by Shepard in The God of Hell, which comprises bold political and unethical instances where corrupt methods are used by Welch-- a barefaced example of government officials. Nonetheless, the voluble bell Emma urgently rings at the end of the play is the playwright's continuous alarming outcry against all environmental, political, social and ethical violations highlighted throughout, so that people may be motivated to address these abuses on their own. 